\title{
Effects of seagrasses and algae of the Caulerpa family on hydrodynamics and particle-trapping rates
}

\author{
Iris E. Hendriks $\cdot$ Tjeerd J. Bouma • \\ Edward P. Morris · Carlos M. Duarte
}

Received: 27 January 2009/ Accepted: 22 October 2009

(C) Springer-Verlag 2009

\begin{abstract}
The widespread decline of seagrass beds within the Mediterranean often results in the replacement of seagrasses by opportunistic green algae of the Caulerpa family. Because Caulerpa beds have a different height, stiffness and density compared to seagrasses, these changes in habitat type modify the interaction of the seafloor with hydrodynamics, influencing key processes such as sediment resuspension and particle trapping. Here, we compare the effects on hydrodynamics and particle trapping of Caulerpa taxifolia, C. racemosa, and C. prolifera with the Mediterranean seagrasses Cymodocea nodosa and Posidonia oceanica. All macrophyte canopies reduced near-bed volumetric flow rates compared to bare sediment, vertical profiles of turbulent kinetic energy revealed peak values around the top of the canopies, and maximum values of Reynolds stress increased by a factor of between 1.4 (C. nodosa) and 324.1 (P. oceanica) when vegetation was present. All canopies enhanced particle retention rates compared to bare sediment. The experimental $C$. prolifera canopy was the most effective at particle retention $\left(\mathrm{m}^{2}\right.$ habitat); however, C. racemosa had the largest particle
\end{abstract}

Communicated by U. Sommer.

I. E. Hendriks $(\bowtie) \cdot$ C. M. Duarte

IMEDEA (CSIC-UIB), Instituto Mediterráneo

de Estudios Avanzados, C/Miquel Marqués 21,

07190 Esporles (Mallorca), Spain

e-mail: iris.hendriks@uib.es

\section{T. J. Bouma}

Netherlands Institute of Ecology (NIOO),

Korringaweg 7, 4401 NT Yerseke, The Netherlands

E. P. Morris

Departemento de Biologia, C.A.S.E.M.,

Universidad de Cádiz, Puerto Real, 11510 Cádiz, Spain retention capacity per structure surface area. Hence, in terms of enhancing particle trapping and reducing hydrodynamic forces at the sediment surface, Caulerpa beds provided a similar or enhanced function compared to P.oceanica and C. nodosa. However, strong seasonality in the leaf area index of $C$. racemosa and $C$. taxifolia within the Mediterranean, combined with a weak rhizome structure, suggests that sediments maybe unprotected during winter storms, when most erosion occurs. Hence, replacement of seagrass beds with Caulerpa is likely to have a major influence on annual sediment dynamics at ecosystem scales.

\section{Introduction}

Seagrass beds are highly productive coastal ecosystems (Bay 1984), providing physical structures that enhance community diversity, biomass and primary and secondary production (Duarte and Chiscano 1999; Duffy 2006) and play a key role in carbon burial (Duarte et al. 2005). The large carbon burial capacity documented for seagrass meadows is strengthened by the role of their canopies in enhancing sediment deposition (Gacia et al. 2002). Seagrasses alter their surrounding physical habitat, since their canopies attenuate turbulence and reduce water flow (Koch et al. 2006), promoting fluxes of particles to the bed (Hendriks et al. 2008) enhancing sedimentation (Koch et al. 2006; Bos et al. 2007) and preventing resuspension (Gacia and Duarte 2001). These intrinsic properties of macrophyte canopies act to stabilize sediments, reduce erosion and turbidity of the overlying water column (Madsen et al. 2001), strongly influencing near-shore sediment dynamics (Marba et al. 2002; van der Heide et al. 2007). 
Mediterranean seagrass meadows, particularly those of the endemic species Posidonia oceanica, are experiencing widespread decline (Marba et al. 1996, 2005; Peirano et al. 2005) due to a combination of direct anthropogenic pressure and climate change (Sánchez-Jerez and Ramos Esplá 1996; Balestri et al. 2004; Pergent-Martini et al. 2006). This decline is offering scope for opportunistic and exotic species to invade these habitats. These include species of the green alga Caulerpa sp. (Occhipinti-Ambrogi and Savini 2003), which include one opportunistic native species (Caulerpa prolifera) and two invasive species, Caulerpa taxifolia and Caulerpa racemosa. The macroalga C. taxifolia invaded the Western Mediterranean as an escapee from an aquarium (Jousson et al. 1998) and C. racemosa invaded the Mediterranean from the Red Sea across the Suez channel (Verlaque et al. 2003). These three species can invade unhealthy Posidonia oceanica meadows (de Villele and Verlaque 1995; Argyrou et al. 1999; Occhipinti-Ambrogi and Savini 2003). Colonization of $P$. oceanica meadows by Caulerpa species seems to be related to stress level in the environment, like for instance, in the vicinity of sewage outfalls and storm water drains as described in Jaubert et al. (2003). The replacement of Mediterranean seagrass by Caulerpa species may affect key ecosystem function and services. In particular, the replacement of seagrass meadows by Caulerpa species is expected to affect the hydrodynamic properties of the seafloor, since the Caulerpa canopies differ greatly in height, stiffness and density from seagrass canopies. This would influence a wide range of key processes, from wave dampening to altered particle (propagules as well as sediment) trapping. However, the effect of this species shift on plant-flow interactions has not yet been assessed.

Here, we evaluate the effects on hydrodynamics and particle trapping of Mediterranean Caulerpa and seagrass species (Cymodocea nodosa and Posidonia oceanica). Three Caulerpa species were compared; the opportunistic, autochthonous Caulerpa prolifera and the invasive, exotic C. taxifolia and $C$. racemosa. Caulerpa-flow interactions are examined experimentally here, whereas seagrass-flow interactions are derived from previous reports (Morris et al. 2008; Hendriks et al. 2008).

\section{Methods}

Hydrodynamic properties and particle-trapping rates of Caulerpa prolifera (Forsskål) J.V. Lamouroux, C. taxifolia (M. Vahl) C. Agardh and C. racemosa (Forsskål) J. Agardh canopies were measured under controlled circumstances in the NIOO flume using an approach previously developed for Posidonia oceanica (Linnaeus) Delile (Hendriks et al. 2008). The algae were collected from the field at around
$5 \mathrm{~m}$ depth, close to the island of Mallorca, Spain, and immediately transported by air in a refrigerated container to the flume facility located at NIOO-KNAW, Yerseke, the Netherlands. This facility was equipped with special measures (physical filters, UV sterilisation of outflow, no direct release to the environment) to prevent release of biological material. Experimental meadows of the algae were set up in the test-section of the flume (dimensions: $2.1 \mathrm{~m}$ long $\times 0.6 \mathrm{~m}$ wide) as patches extending $0.5 \mathrm{~m}$ in length across the total flume width. The macrophytes were planted in the test-section on a smooth bed of silica sand with an average grain size $\left(k_{s}\right)$ of $249 \pm 13 \mu \mathrm{m}$ ( \pm standard error, SE). Rhizome and frond density as well as dry weight of the algae were determined (Table 1). Water temperature was maintained at $14 \pm 0.2^{\circ} \mathrm{C}$, while salinity was held constant at 35\%.

We compared the results obtained with those derived from the Mediterranean seagrasses Posidonia oceanica (Hendriks et al. 2008) and Cymodocea nodosa (Ucria) Ascherson (Morris et al. 2008) in the same flume under comparable experimental conditions.

\section{Leaf area index}

The macrophytes examined differed greatly in size and shape (Fig. 1). Surface area of Caulerpa prolifera fronds was calculated as the area of an ellipse $\pi a b$, where $a$ is 0.5 frond length and $b$ is 0.5 width. The (normally distributed) length (and width) distribution of a random selection of fronds in the test-section $(n=47)$ was multiplied by the frond density to obtain an estimate of the total surface area covered by the fronds. The surface area of Caulerpa racemosa was calculated as the accumulated surface of the average amount of sphere-like structures (3, calculated as $4 \pi r^{2}$ ) protruding from the rhizome for average height of the algae in the test-section $(n=120)$. The surface area of Caulerpa taxifolia was calculated $(n=95)$ with Jimage ${ }^{\mathrm{TM}}$ image analyses software after processing the images in Adobe Photoshop ${ }^{\mathrm{TM}}$. Parameters for Cymodosa nodosa were extracted from Morris et al. (2008), while data for Posidonia oceanica were derived from (Hendriks et al. 2008). All parameters are summarised in Table 1.

Hydrodynamic properties of the canopy

Hydrodynamic properties and particle-trapping rates of the canopies were measured under controlled conditions in a racetrack flume (described in detail in Hendriks et al. 2006; also see http://www.nioo.nl/science/facilities/flume/flume. $\mathrm{htm})$. Water depth in the canal was $0.38 \mathrm{~m}$ for all experimental treatments. Flow measurements were carried out with a Nortek Acoustic Doppler Velocimeter (ADV), mounted on a 3D positioning system, where $x$ was defined 
Table 1 Leaf or frond density, average length, biomass, LAI and bed length for the experimental meadows

\begin{tabular}{|c|c|c|c|c|c|}
\hline Species & Density $\left(\mathrm{m}^{-2}\right)$ & $\begin{array}{l}\text { Length } \\
(\mathrm{m} \pm \mathrm{SE})\end{array}$ & $\begin{array}{l}\text { DW } \\
\left(\mathrm{g} \mathrm{m}^{-2}\right)\end{array}$ & $\begin{array}{l}\text { LAI } \\
\left(\mathrm{m}^{2} \mathrm{~m}^{-2}\right)\end{array}$ & $\begin{array}{l}\text { Bed length } \\
\text { (m) }\end{array}$ \\
\hline Caulerpa prolifera & 2003 & $0.06 \pm 0.004$ & 15.5 & 0.979 & 0.5 \\
\hline Caulerpa taxifolia & 1570 & $0.11 \pm 0.003$ & 297.7 & $3.26 \pm 0.666$ & 0.5 \\
\hline Caulerpa racemosa & 6667 & $0.01 \pm 0.002$ & 43.1 & 0.251 & 0.5 \\
\hline Cymodocea nodosa $a^{\mathrm{a}}$ & 1820 & $0.18 \pm 0.017$ & 40.0 & 1.67 & 2.0 \\
\hline Posidonia oceanica ${ }^{\mathrm{b}}$ & $785-761$ & $0.13 \pm 0.003$ & 120.0 & $0.797-0.772$ & 1.0 \\
\hline
\end{tabular}

${ }^{a}$ From Morris et al. (2008)

b From Hendriks et al. (2008)

Fig. 1 Schematic drawing presenting the size and shape differences of the tested macrophytes. From left to right Caulerpa racemosa, C. prolifera, C. taxifolia, Posidonia oceanica and Cymodocea nodosa. The scale bar on the left represents $1 \mathrm{~cm}$
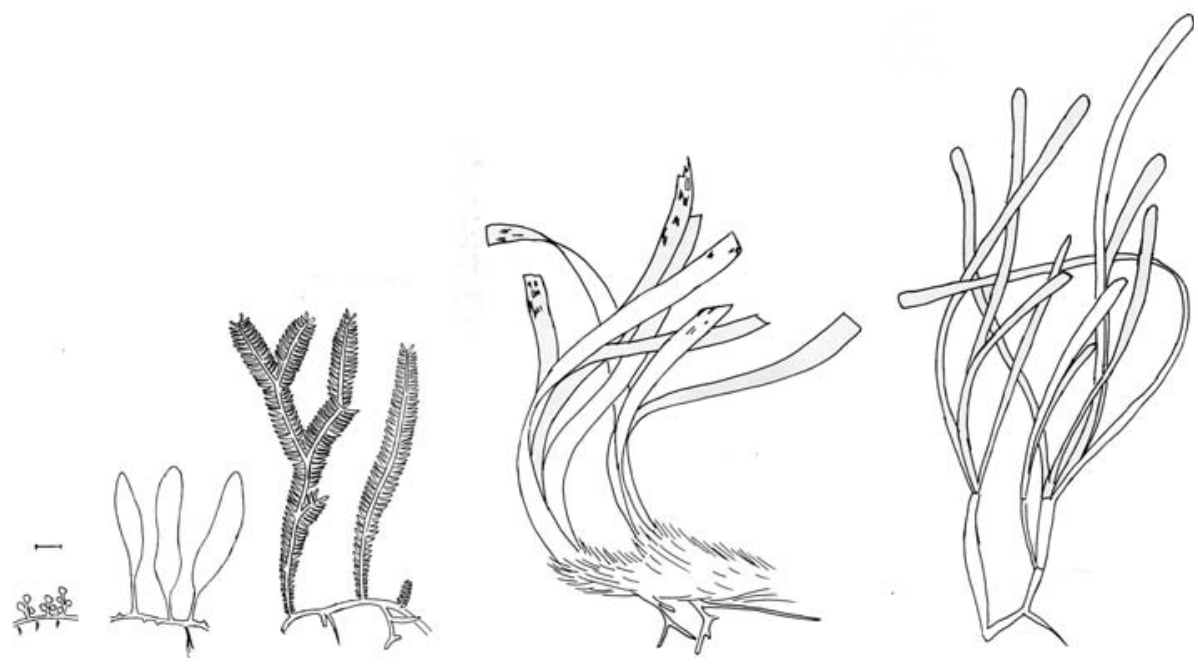

as the main flow direction, $y$ across the flume channel and $z$ the vertical. Two experimental free stream velocity $\left(U_{\infty}\right)$ treatments $\left(0.05\right.$ and $\left.0.10 \mathrm{~m} \mathrm{~s}^{-1}\right)$ were applied. Time series of velocities were measured as duplicate vertical profiles as far advanced in the meadow as possible, around $0.4 \mathrm{~m}$ from the leading edge to avoid edge effects at the back of the canopy. Vertical positions ranged from close to the bed $(z=0.005 \mathrm{~m})$ to outside the boundary layer $(z=0.161 \mathrm{~m})$ when measuring over bare sediment. Step size was $0.008 \mathrm{~m}$ for the lower part of the profile $(0.005-0.101 \mathrm{~m})$ and $0.01 \mathrm{~m}$ for the upper part of the profile $(0.101-0.161 \mathrm{~m})$. For each position in the flow profile, three-dimensional flow velocity measurements were sampled at a rate of $25 \mathrm{~Hz}$ over a period of $330 \mathrm{~s}$ resulting in ample resolution for turbulence calculations.

The integrated volumetric flow rate from the sediment surface up until the canopy height $(d)$ was calculated as $\int_{z=0}^{z=d} \bar{U} d z$ (Gambi et al. 1990). From point measurements over time, the means of individual velocity components $u$, $v$ and $w$ (corresponding to velocities in the $x, y$ and $z$ direction) were calculated. From these, turbulence kinetic energy (TKE, $0.5 *\left(\overline{u^{\prime 2}}+\overline{v^{\prime 2}}+\overline{w^{\prime 2}}\right)$, in $\mathrm{m}^{2} \mathrm{~s}^{-2}$ ) and Reynolds stress $\rho\left(\overline{u^{\prime} w^{\prime}}\right)$ (in $\mathrm{Pa}$ or $\mathrm{N} \mathrm{m}^{-2}$ ) were calculated.
Reynolds stress can be thought of as the vertical flux of momentum describing vertical transfer $\left(w^{\prime}\right)$ of longitudinal momentum fluctuations $\left(u^{\prime}\right)$, an indicator of vertical mixing activity (Velasco et al. 2003). According to the Reynolds' analogy for the equivalence of mass and momentum transfer in turbulent shear flow (Jobson and Sayre 1970), negative Reynolds stresses indicate diffusivity of momentum from the water column to the sediment that could be similar to the diffusivity of a scalar and depending on the gradient, be a rough proxy for transport of mass. Comparing profiles in control (sand) situations with vegetated treatments indicates the flow reduction and increased transport of particles attributed to hydrodynamic changes due to the presence of the canopy.

\section{Particle retention in canopies}

Particle concentration in the water column of the flume was measured experimentally with two optical backscattering sensors (OBS). No significant drift was observed in the output signal of the OBS between the start and end of the experiments. Deep-sea sediment particles (size range approx. 1-3 $\mu \mathrm{m}$, with negligible inherent vertical velocity (w) calculated with Stoke's law as approx. $4 \times 10^{-6} \mathrm{~m} \mathrm{~s}^{-1}$ ) 
were seeded to the flume, and their concentration measured every $15 \mathrm{~min}$ (C. prolifera and Posidonia oceanica) or $10 \mathrm{~s}$ (C. racemosa, C. taxifolia and Cymodocea nodosa). The difference in time interval is due to an improvement in the OBS measuring system made during the experiment. Control measurements, where the test-section only contained bare sand without plants, were performed to obtain a background retention rate of the flume (i.e., loss of particles due to adhesion to the flume and sand surfaces). Measurements were taken in duplo within the test-section at $0.28 \mathrm{~m}$ above the sediment surface. After sediment addition, the water in the flume was mixed vigorously for $3 \mathrm{~min}$, before returning the settings to the treatment flow velocity and starting the measurements. OBS measurements were carried out over a time period of 2700s (45 min). Dispersal of the particles with the flume water column $\left(10 \mathrm{~m}^{3}\right)$ was not complete, rather a cloud of particles could be observed circulating within the canal. Hence, during analysis of the rate of particle decrease, only maximum backscatter values (i.e., the circulating sediment cloud) were used.

The particle loss rate can be described using the equation:

$N_{t}=a+N_{0} \cdot e^{-k t}$

where $N_{t}$ and $N_{0}$ are the particle concentration at time $t$ and $0, a$ is the background particle concentration and $k$ is a firstorder rate constant. This equation should render a distinctive $k$ for a flume with and without vegetation. $k$ is composed of an effective particle loss rate attributed to the vegetation $\left(k_{v}\right)$, which acts over the small area where the bed is present $\left(0.3-1.2 \mathrm{~m}^{2}\right)$ and the background loss rate for the remaining distance travelled in the flume i.e., $k$ measured without vegetation ( $k_{\mathrm{SAND}}$, Hendriks et al. 2008). Since the flume has a length $(L)$ of $41 \mathrm{~m}$, the time $\left(t_{1}\right)$ needed for the fluid to circulate once (one lap) at a given flow velocity $u_{\infty}\left(\mathrm{m} \mathrm{s}^{-1}\right)$ is:

$t_{1}=L / u_{\infty}$

$k_{\mathrm{v}}\left(\mathrm{s}^{-1}\right)$ is obtained by taking into account the amount of time fluid spends within the vegetation $\left(t_{v}\right)$ and the relative volume of water passing through the canopy $(\alpha)$. Calculated as:

$t_{v}=l_{0} / u_{v}$

$\alpha=V_{v} / V_{F}$

where $u_{v}$ is the mean water velocity $\left(\mathrm{m} \mathrm{s}^{-1}\right)$ within the canopy, $l_{0}$ is the length the bed $(\mathrm{m}), V_{v}$ is the rectangular volume occupied by the canopy $\left(\mathrm{m}^{3}\right)$ and $V_{F}$ is the volume of the flume tank (app. $10 \mathrm{~m}^{3}$ ). Hence, $k_{v}$ can be derived by solving the equation:

$e^{-k t_{1}}=(1-\alpha) e^{-k_{\mathrm{SAND}} t_{1}}+\alpha e^{-k_{v} t_{v}}$
Using this vegetation-specific rate of particle trapping we calculated the time required to reduce water-column sediment concentrations by $50 \%$.

\section{Results}

Hydrodynamic properties of the canopy

Comparison of vertical profiles of $\mathrm{u}\left(\mathrm{m} \mathrm{s}^{-1}\right)$ measured over bare sediment with profiles within Caulerpa and seagrass canopies (Fig. 2a-d) demonstrated the attenuating effect of all canopy types on flow velocity. Volumetric flow rate through the canopies were reduced by between $31 \%$ (Cymodocea nodosa) and 88\% (Cualerpa taxifolia) compared to the control (Table 2). Significant differences in the magnitude of flow reduction were found between the different species (ANOVA, $F_{4,9}=40.52, P<0.001$ ). Flow reduction by the canopy of the alga $C$. taxifolia was highest, no difference in attenuation of flow was found between Posidonia oceanica, Caulerpa prolifera and Caulerpa racemosa $(P>0.35)$, and Cymodocea nodosa had the lowest flow attenuation (Post hoc Tukey test, $P<0.05$ ).

Vertical profiles of Reynolds stress (Fig. 3a-d) and turbulent kinetic energy (TKE) (Fig. 4a-d) had peak values around the canopy height and lower values in the near-bed region (although often substantially larger than the control). Maximum values of Reynolds stress increased by a factor of between 324.1 ( $P$. oceanica) and 1.4 ( $C$. nodosa) times compared to bare sediment when vegetation was present (Table 2). Thus, according to the Reynolds' analogy for the equivalence of mass and momentum transfer in turbulent shear flow, dependent on the gradient of particles in the water column, a proportional increase in the transport of mass (particles) into the canopy area is predicted in all of the vegetation treatments.

Particle retention in canopies

Particle retention in the flume was an efficient process even when vegetation was not present, always resulting in a strong exponential decrease in water-column particle concentration $(k)$. After correction for the background loss rate, the area of flume occupied by the bed and the proportion of flow passing through the canopy, $k_{v}$ values were two orders of magnitude larger than $k_{\text {SAND }}$ (Table 3 ). The time required to retain $50 \%$ of the sediment concentration when only the specified vegetated or control treatment was influencing particle decrease is very short (Table 3 ). The most effective vegetation for retaining particles was the $C$. taxifolia canopy, followed by $C$. nodosa, $C$. prolifera, $P$. oceanica, $C$. racemosa and finally the sand control. However, these macrophyte canopies differ 
Fig. 2 Current velocity profiles under free stream flow velocities of a 0.05 and b $0.10 \mathrm{~m} \mathrm{~s}^{-1}$ above Caulerpa canopies. The solid line is the reference profile (over siliceous sediments). Solid horizontal lines are average canopy heights (top to bottom C. taxifolia; C. prolifera; C. racemosa). Flow profiles of Posidonia oceanica (Hendriks et al. 2008) and Cymodocea nodosa (Morris et al. 2008) under free stream flow velocities of $\mathbf{c} 0.05$ and d $0.10 \mathrm{~m} \mathrm{~s}^{-1}$. The solid line represents the reference profile (over siliceous sediments). Solid horizontal lines are average canopy heights (top to bottom Cymodocea; Posidonia)

Table 2 Effects on flow by Caulerpa sp. canopies and seagrass canopies
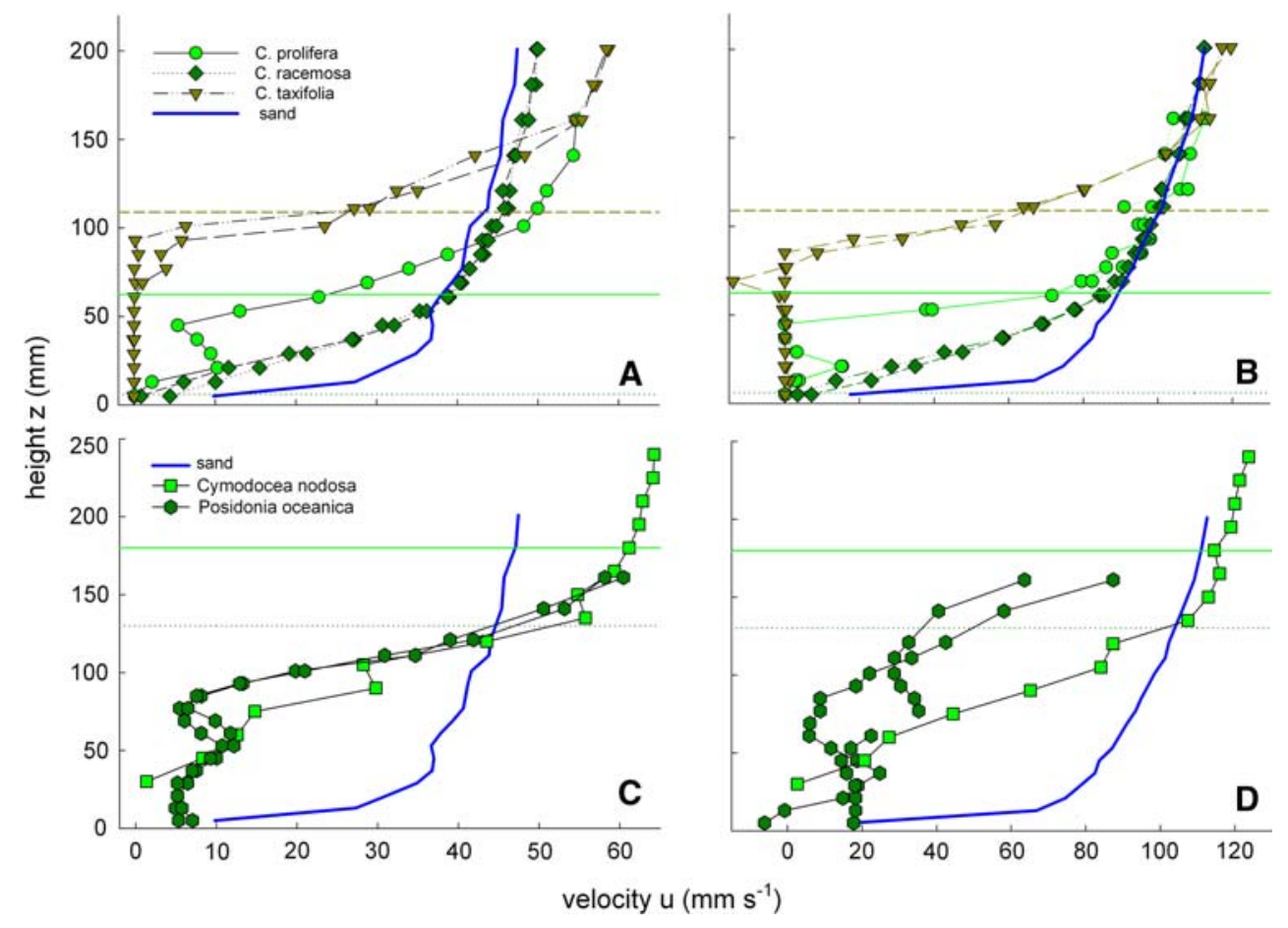

\begin{tabular}{lllcc}
\hline Species & $U_{\infty}$ & $\begin{array}{l}\text { Flow } \\
\text { reduction }(\%)\end{array}$ & $\begin{array}{l}\text { Peak Reynolds } \\
\text { stress increase }\end{array}$ & $\begin{array}{l}\text { \% Flow reduction } \\
\mathrm{m}^{-2} \text { leaf area }\end{array}$ \\
\hline C. racemosa & 0.05 & 73.1 & 9.0 & 291.4 \\
& 0.10 & 76.4 & 6.4 & 304.6 \\
C. prolifera & 0.05 & 76.0 & 21.5 & 77.6 \\
& 0.10 & 64.0 & 119.1 & 65.3 \\
C. taxifolia & 0.05 & 88.0 & 128.0 & 27.2 \\
& 0.10 & 86.0 & 9.5 & 26.6 \\
Cymodocea nodosa $^{\text {a }}$ & 0.05 & 34.9 & 49.6 & 20.9 \\
& 0.10 & 30.5 & 1.4 & 87.3 \\
Posidonia oceanica $^{\mathrm{b}}$ & 0.05 & 69.6 & 324.1 & 93.9 \\
& 0.10 & 74.9 & 91.2 & \\
\hline
\end{tabular}

a Calculated from data of Morris et al. (2008), profiles at $0.5 \mathrm{~m}$ in the canopy

b Calculated from data of Hendriks et al. (2008)
$(P<0.001)$. Flow reduction within the canopy of the alga Caulerpa taxifolia was highest, which was probably due to the high frond density of the experimental bed combined with the high surface area and stiffness of individual fronds. There was no significant difference in the attenuation of volumetric canopy flow between Posidonia oceanica, Caulerpa prolifera and Caulerpa racemosa $(P>0.35)$, while Cymodocea nodosa had the lowest attenuation of volumetric flow $(P<0.005)$. A possible explanation is that leaves of $C$. nodosa are very flexible, and because they bend in the flow, the actual surface exposed to the flow is much smaller than calculated. When normalised to the surface area of structures, C. racemosa and $P$. oceanica attenuated flow considerably more than the other macrophytes. P. oceanica shoots were collected in winter, when leaves were short, positioned upright and are
Significant differences in the reduction of flow within the canopies of the different species were observed 
Fig. 3 Reynolds stress profiles under free stream flow velocities of a 0.05 and b $0.10 \mathrm{~m} \mathrm{~s}^{-1}$ above Caulerpa canopies. The solid line is the reference profile (over siliceous sediments). Solid horizontal lines are average canopy heights (top to bottom C. taxifolia; C. prolifera; C. racemosa). Reynolds stress profiles of Posidonia oceanica (Hendriks et al. 2008) and Cymodocea nodosa (Morris et al. 2008) under free stream flow velocities of c 0.05 and d $0.10 \mathrm{~m} \mathrm{~s}^{-1}$. The solid line represents the reference profile (over siliceous sediments). Solid horizontal lines are average canopy heights (top to bottom Cymodocea; Posidonia)

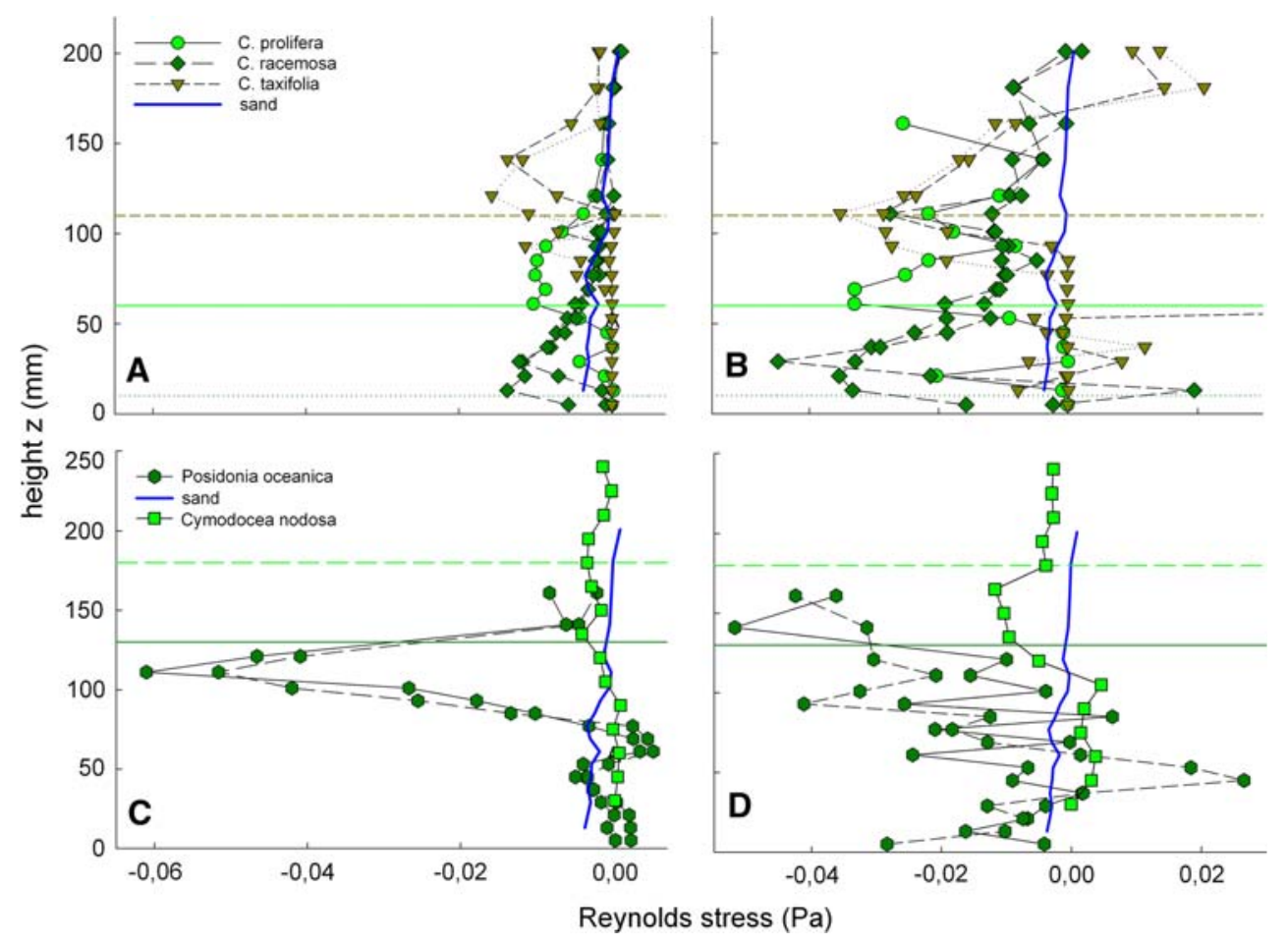

Fig. 4 Turbulent kinetic energy (TKE) profiles under free stream flow velocities of a 0.05 and $\mathbf{b} 0.10 \mathrm{~m} \mathrm{~s}^{-1}$ above Caulerpa canopies. The solid line is the reference profile (over siliceous sediments). Solid horizontal lines are average canopy heights (top to bottom C. taxifolia; C. prolifera; C. racemosa). Turbulent kinetic energy (TKE) profiles of Posidonia oceanica (Hendriks et al. 2008) and Cymodocea nodosa (Morris et al. 2008) under free stream flow velocities of $\mathbf{c} 0.05$ and d $0.10 \mathrm{~m} \mathrm{~s}^{-1}$. The solid line represents the reference profile (over siliceous sediments). Solid horizontal lines are average canopy heights (top to bottom Cymodocea; Posidonia)
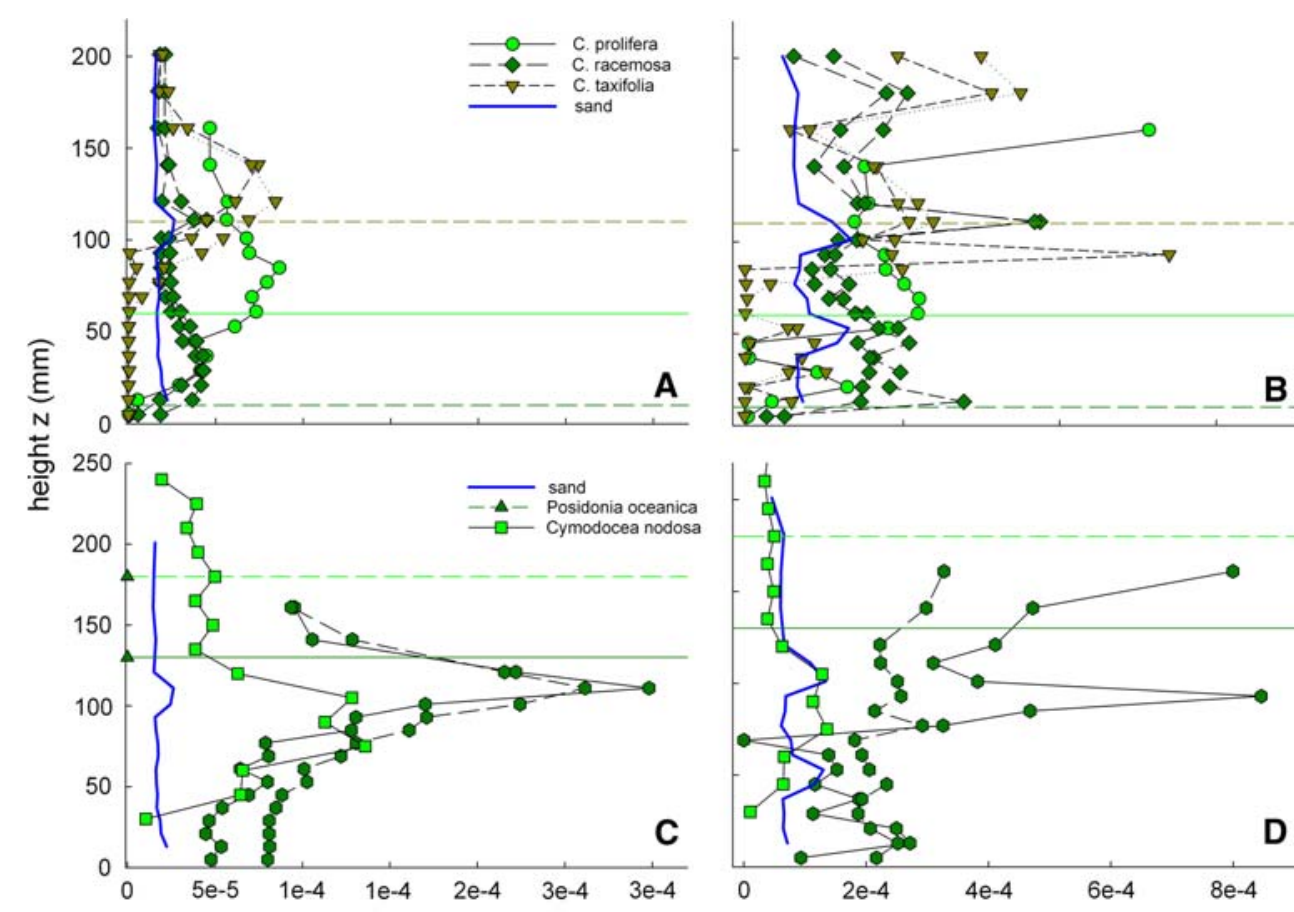

TKE $\left(\mathrm{m}^{2} \mathrm{~s}^{2}\right)$ relatively stiff, and $C$. racemosa structures stand upright and are rigid. Hence, stiffness-flexibility appears to have a strong influence on the interaction of hydrodynamics with aquatic plants (Peralta et al. 2008). Thus, the effects of different macrophyte canopies on near-bed hydrodynamics was dependent on the specific properties of each canopy suggesting that prediction of flow interactions maybe possible if simple architectural traits (density, stiffness, morphology etc.) of each species are known.

Considering, as a rule of thumb, that fully developed velocity profiles are usually observed at a distance of approximately 10 times the canopy height from the leading edge of the bed (Ghisalberti and Nepf 2002; Nepf et al. 2007), the horizontal position at which hydrodynamic 
Table 3 Particle retention by Caulerpa sp. canopies and seagrass canopies at $0.05 \mathrm{~m} \mathrm{~s}^{-1}$ free stream velocity. Optical backscattering (OBS) profiles from $0.28 \mathrm{~m}$ height above the bottom

\begin{tabular}{|c|c|c|c|c|}
\hline Species & $K(\mathrm{SE})$ & $K_{v}$ & $\begin{array}{l}\text { Time }\left(\mathrm{s}^{-1}\right) \text { to retain } \\
50 \% \text { sediment conc. }\end{array}$ & $\begin{array}{l}\% \text { Retained }(5 \mathrm{~min}) \\
\text { per } \mathrm{m}^{2} \text { leaf area }\end{array}$ \\
\hline Sand (control) & $7 \times 10^{-4}\left(6 \times 10^{-5}\right)$ & $7 \times 10^{-4}\left(6 \times 10^{-5}\right)$ & 990 & - \\
\hline C. racemosa & $9 \times 10^{-4}\left(5 \times 10^{-5}\right)$ & $0.029(0.001)$ & 24 & 304.01 \\
\hline C. prolifera ${ }^{\mathrm{a}}$ & $0.001\left(1 \times 10^{-4}\right)$ & $0.091(0.002)$ & 8 & 101.04 \\
\hline C. taxifolia & $0.0011\left(6 \times 10^{-5}\right)$ & $0.027(0.001)$ & 28 & 22.6 \\
\hline Cymodocea nodosa & $0.0013\left(6 \times 10^{-5}\right)$ & $0.036(0.002)$ & 19 & 69.63 \\
\hline Posidonia oceanica $^{\mathrm{a}}$ & $6 \times 10^{-4}$ & 0.038 & 18 & 106.67 \\
\hline
\end{tabular}

First-order rate constant $\mathrm{k}$ from the exponential part of the concentration graph, $\mathrm{k}_{\mathrm{v}}$ is the effective first-order rate constant for the vegetation. Retained sediment based on effective $\mathrm{k}_{\mathrm{v}}$ in model $N_{t}=N_{0} e^{-k t}$

${ }^{a}$ Control values for the sand treatment during this experiment were $3 \times 10^{-5}$, all values are recalculated from the original data, different time span (Hendriks et al. 2008)

profiles were collected $(x=0.4 \mathrm{~m})$, meant for most experimental canopies that the velocity profiles represented transitional flow regions. Only in the case of $C$. racemosa (length $=0.01 \pm 0.002 \mathrm{~m}$ ) could the velocity profile be considered fully developed. Hence, hydrodynamic profiles from our experiment should be interpreted as measurements in transitional flow regions (flow profiles over small beds) and not as representations of fully developed flow (flow profiles over very large beds). Logistic constraints made it impossible to transport larger beds to the laboratory. On the other hand, as small patches of Caulerpa are a common occurrence at the field site, our experimental canopies are comparable to macrophyte landscapes found in natural conditions.

Vertical profiles of Reynolds stress and turbulent kinetic energy (TKE) within the seagrass canopies had maximum values just below the canopy height, while peaks in turbulence within algal canopies were observed just above the canopy height (Figs. 3, 4c, d; Table 2). All canopies increased the values of maximum turbulence compared to bare sediment; however, importantly, the presence of the canopy meant that the vertical region with maximum turbulence was substantially shifted away from the bed. In the near-bed region, where shear forces may induce sediment movement, TKE and Reynolds stresses tended towards zero.

Even though increases in peak Reynolds stress at the top of the canopy of $C$. racemosa were only 9 times higher than control profiles (Table 2), this species had a high particletrapping potential when normalised to surface area (Table 3). Values above $100 \%$ flow reduction and retained sediment (Table 3 ) are obtained because the flow reduction is calculated for $\mathrm{m}^{2}$ leaf area and the accumulated surface of $C$. racemosa did not add up to a meter square in the testsection. The small size of this species, combined with the high density of the stiff structures protruding from the bed, probably induces a 'skimming flow' type of hydrodynamic regime over the bed (i.e., a fast flowing layer above the canopy with very little advective water movement within the canopy). This strong vertical divergence in flow velocity induces sheer, resulting in turbulent mixing of the two layers and presumably an increased transport of particles into the canopy. This mechanism of particle transport contrasts with the other species examined, where transport was mainly by advection through the leading edge; flow was not fully developed as the ratio of bed length to canopy height was $<10$. With the short canopy height of $C$. racemosa, the experimental bed was long enough to allow fully developed flow, enabling turbulent transport to dominate.

C. racemosa is known to tolerate increased sedimentation, and its growth even seems to be enhanced under these circumstances; the species is highly resistant to disturbances (Piazzi et al. 2005). Thus, enhanced sedimentation may be one of the mechanisms by which $C$. racemosa is able to exclude slower growing benthic macrophyte species.

Differences between experimental settings, such as bed length and variation in initial particle concentration make the direct results of particle-trapping difficult to compare. For example, initial sediment concentrations above the Cymodocea nodosa canopy were 5 times higher than the canopies of $C$. taxifolia and $C$. racemosa, leading to absolute retentions of $10.5 \mathrm{mg}^{-1}$ in $15 \mathrm{~min}$ for $C$. nodosa and 1.1 and $0.7 \mathrm{mg}^{-1}$ for the respective Caulerpa species. However, by calculating an effective retention coefficient $\left(k_{v}\right)$ for the canopies, we have been able to provide a robust comparative assessment of flow attenuation and particle retention within canopies of Caulerpa sp. and seagrass species (Table 2 and 3). Our model assumes particle retention by the canopy due to advection, which is probably the dominant mechanism for short canopies (less than 10 times canopy height). 
Effects of replacement of seagrass meadows by opportunistic algae

As demonstrated in this study, an important aspect of the replacement of seagrass meadows by invasive algae is the change in the hydrodynamic properties of the seafloor, potentially influencing a wide range of processes and in particular the particle (propagules as well as sediment) flux to the seafloor. Changes in the dominant phytobenthic cover will influence sediment biochemistry, nutrient cycling, water-column oxygen profiles, water filtration capacity, primary and secondary production, carbon storage, support of higher trophic levels and the ecosystems response to disturbance (Ceccherelli and Cinelli 1997). Thus, replacement of highly productive seagrass ecosystems with algal species such as Caulerpa is likely to change the functioning of the local ecosystem. Associated species are different in seagrass meadows and Caulerpa assemblages; for example, phytobenthic community diversity dramatically changes (Piazzi et al. 2001, 2005), and increased diversity and abundance of polychaetes (often an indicator of sediment organic matter enrichment) are often found after $C$. racemosa invasion (Argyrou et al. 1999). Hence, a full account of the change in ecosystem services resulting from the loss of seagrass habitat involves the evaluation of how many functions (e.g., production, carbon sequestration, biodiversity maintenance) are influenced by the change in hydrodynamic properties of the seafloor.

In the case of Mediterranean seagrasses being replaced by opportunistic Caulerpa macroalgae, the seafloor will retain its capacity to reduce flow velocities, trap particles and retain sediments; Caulerpa attenuated flow, trapped particles and protected the sediment from erosion as well as or even better than seagrasses. For example, Caulerpa racemosa, which is rapidly spreading through the Mediterranean at present (Piazzi et al. 2001), was the most effective, per unit surface area, at retaining particles. On the other hand, differences in the seasonality and structural properties between Caulerpa spp., and seagrasses suggest annual sediment dynamics are likely to be affected. C. racemosa (Piazzi et al. 2001) and C. taxifolia (Ceccherelli and Cinelli 1998) both have a greatly diminished biomass in winter, and in contrast to the seagrasses, they lack a pronounced rhizome structure that binds the sediment; hence, during winter, sediments are likely to be exposed to erosion.

In conclusion, changes in the hydrodynamic properties of the seafloor caused by the loss of Mediterranean seagrasses may be less dramatic in summer when these meadows are replaced by Caulerpa species, which have a similar influence on near-bed hydrodynamics. However, during winter (when most large storms occur), these species have limited coverage and/or reduced sizes, suggesting that erosion of the unprotected sediment could be dramatic.

Acknowledgments This research was funded by the European Network of Excellence "Marine Biodiversity and Ecosystem Function" (MarBEF); FP6, EC contract no. 505446 and a grant from the Fundación BBVA. EPM was supported by a European Union Marie Curie host fellowship for transfer of knowledge, MTKD-CT-2004509254, the Spanish national project EVAMARIA (CTM2005-00395/ MAR) and the regional government of Andalusia project FUNDIV (P07-RNM-2516). We thank G. Tavecchia for help with analyses, L. van IJzerloo for assisting with the calibration of the equipment and J. van Soelen for preparing equipment and processing of samples. Carlo Heip is gratefully acknowledged for granting access to the flume facilities at NIOO-KNAW, CEME and Luca van Duren for taking care of the sterilization unit and filters.

\section{References}

Argyrou M, Demetropoulos A, Hadjichristophorou M (1999) Expansion of the macroalga Caulerpa racemosa and changes in softbottom macrofaunal assemblages in Moni Bay, Cyprus. Oceanol Acta 22:517-528

Balestri E, Benedetti-Cecchi L, Lardicci C (2004) Variability in patterns of growth and morphology of Posidonia oceanica exposed to urban and industrial wastes: contrasts with two reference locations. J Exp Mar Biol Ecol 308:1-21

Bay D (1984) A field study of the growth dynamics and productivity of Posidonia oceanica (L.) delile in Calvi Bay, Corsica. Aquat Bot 20:43-64

Bos ARR, Bouma TJ, de Kort GLJ, van Katwijk MM (2007) Ecosystem engineering by annual intertidal seagrass beds: sediment accretion and modification. Estuar Coast Shelf Sci 74:344-348

Ceccherelli G, Cinelli F (1997) Short-term effects of nutrient enrichment of the sediment and interactions between the seagrass Cymodocea nodosa and the introduced green alga Caulerpa taxifolia in a Mediterranean bay. J Exp Mar Biol Ecol 217:165-177

Ceccherelli G, Cinelli F (1998) Habitat effect on spatio-temporal variability in size and density of the introduced alga Caulerpa taxifolia. Mar Ecol Prog Ser 163:289-294

de Villele X, Verlaque M (1995) Changes and degradation in a Posidonia oceanica bed invaded by the introduced tropical alga Caulerpa taxifolia in the north western Mediterranean. Botanica Marina 38:79-87

Duarte CM, Chiscano CL (1999) Seagrass biomass and production: a reassessment. Aquat Bot 65:159-174

Duarte CM, Middelburg JJ, Caraco N (2005) Major role of marine vegetation on the oceanic carbon cycle. Biogeosciences 2:1-8

Duffy JE (2006) Biodiversity and the functioning of seagrass ecosystems. Mar Ecol Prog Ser 311:233-250

Gacia E, Duarte CM (2001) Sediment retention by a Mediterranean Posidonia oceanica meadow: the balance between deposition and resuspension. Estuar Coast Shelf Sci 52:505-514

Gacia E, Duarte CM, Middelburg JJ (2002) Carbon and nutrient deposition in a Mediterranean seagrass (Posidonia oceanica) meadow. Limnol Oceanogr 47:23-32

Gambi MC, Nowell ARM, Jumars PA (1990) Flume observations on flow dynamics in Zostera marina (Eelgrass) beds. Mar Ecol Prog Ser 61:159-169

Ghisalberti M, Nepf HM (2002) Mixing layers and coherent structures in vegetated aquatic flows. J Geophys Res 107(C2):3011. doi: 10.1029/2001JC000871 
Hendriks IE, van Duren LA, Herman PMJ (2006) Turbulence levels in a flume compared to the field: implications for larval settlement studies. J Sea Res 55:15-29

Hendriks IE, Sintes T, Bouma TJ, Duarte CM (2008) Experimental assessment and modeling evaluation of the effects of seagrass (Posidonia oceanica) on flow and particle trapping. Mar Ecol Prog Ser 356:163-173

Jaubert JM, Chisholm JRM, Minghelli-Roman A, Marchioretti M, Morrow JH, Ripley HT (2003) Re-evaluation of the extent of Caulerpa taxifolia development in the northern Mediterranean using airborne spectrographic sensing. Mar Ecol Prog Ser 263:75-82

Jobson HE, Sayre WW (1970) Vertical transfer in open channel flow. J Hydraulic Eng 96:703-724

Jousson O, Pawlowski J, Zaninetti L, Meinesz A, Boudouresque CF (1998) Molecular evidence for the aquarium origin of the green alga Caulerpa taxifolia introduced to the Mediterranean Sea. Mar Ecol Prog Ser 172:275-280

Koch EW, Ackerman JD, Verduin J, van Keulen M (2006) Fluid dynamics in seagrass ecology-from molecules to ecosystems. In: Larkum AWD, Orth RJ, Duarte CM (eds) Seagrasses: biology, ecology and conservation. Springer, Dordrecht, pp 193225

Madsen JD, Chambers PA, James WF, Koch EW, Westlake DF (2001) The interaction between water movement, sediment dynamics and submersed macrophytes. Hydrobiologia 444:7184

Marba N, Duarte CM, Cebrian J, Gallegos ME, Olesen B, SandJensen K (1996) Growth and population dynamics of Posidonia oceanica on the Spanish Mediterranean coast: elucidating seagrass decline. Mar Ecol Prog Ser 137:203-213

Marba N, Duarte CM, Holmer M, Martinez R, Basterretxea G, Orfila A, Jordi A, Tintore J (2002) Effectiveness of protection of seagrass (Posidonia oceanica) populations in Cabrera National Park (Spain). Environ Conserv 29:509-518

Marba N, Duarte CM, Diaz-Almela E, Terrados J, Alvarez E, Martiinez R, Santiago R, Gacia E, Grau AM (2005) Direct evidence of imbalanced seagrass (Posidonia oceanica) shoot population dynamics in the Spanish Mediterranean. Estuaries 28:53-62

Morris EP, Peralta G, Brun FG, van Duren L, Bouma TJ, PerezLlorens JL (2008) Interaction between hydrodynamics and seagrass canopy structure: spatially explicit effects on ammonium uptake rates. Limnol Oceanogr 53:1531-1539
Nepf H, Ghisalberti M, White B, Murphy E (2007) Retention time and dispersion associated with submerged aquatic canopies. Water Resour Res 43(W04422) doi:10.1029/2006WR005362

Occhipinti-Ambrogi A, Savini D (2003) Biological invasions as a component of global change in stressed marine ecosystems. Mar Pollut Bull 46:542-551

Peirano A, Damasso V, Montefalcone M, Morri C, Bianchi CN (2005) Effects of climate, invasive species and anthropogenic impacts on the growth of the seagrass Posidonia oceanica (L.) Delile in Liguria (NW Mediterranean Sea). Mar Pollut Bull 50:817-822

Peralta G, van Duren LA, Morris EP, Bouma TJ (2008) Consequences of shoot density and stiffness for ecosystem engineering benthic macrophytes in flow dominated areas: a hydrodynamic flume study. Mar Ecol Prog Ser 368:103-115

Pergent-Martini C, Boudouresque CF, Pasqualini V, Pergent G (2006) Impact of fish farming facilities on Posidonia oceanica meadows: a review. Mar Ecol Evol Perspect 27:310-319

Piazzi L, Ceccherelli G, Cinelli F (2001) Threat to macroalgal diversity: effects of the introduced green alga Caulerpa racemosa in the Mediterranean. Mar Ecol Prog Ser 210:149-159

Piazzi L, Balata D, Ceccherelli G, Cinelli F (2005) Interactive effect of sedimentation and Caulerpa racemosa var. cylindracea invasion on macroalgal assemblages in the Mediterranean Sea. Estuar Coast Shelf Sci 64:467-474

Sánchez-Jerez P, Ramos Esplá AA (1996) Detection of environmental impacts by bottom trawling on Posidonia oceanica (L.) Delile meadows: sensitivity of fish and macroinvertebrate communities. J Aquat Ecosyst Stress Recov 5:239-253

van der Heide T, van Nes EH, Geerling GW, Smolders AJP, Bouma TJ, van Katwijk MM (2007) Positive feedbacks in seagrass ecosystems: implications for success in conservation and restoration. Ecosystems 10:1311-1322

Velasco D, Bateman A, Redondo JM, DeMedina V (2003) An open channel flow experiment and theoretical study of resistance and turbulent characterization over flexible vegetated linings. Flow Turbulence Combustion 70:69-88

Verlaque M, Durand C, Huisman JM, Boudouresque CF, Le Parco Y (2003) On the identity and origin of the Mediterranean invasive Caulerpa racemosa (Caulerpales, Chlorophyta). Eur J Phycol 38:325-339 